\title{
Molecular Weight of Renal Renin
}

\author{
Kenichi Morimoto, M.D., Masato Matsunaga, M.D., * \\ Akira Hara, M.D., Chun Ho PAK, M.D., Hiroyuki Nagai, M.D., \\ Hisashi Hamada** and Chuichi Kawar, M.D.
}

\section{SUMMARY}

Different forms of renin in the kidney and their relations were investigated by gel-filtration with sephadex G-75. Low molecular weight renin (M.W. 45,000) was found in both of intact Wistar-Kyoto rat (WKY) and WKY whose renin-angiotensin system was stimulated by adrenalectomy and feeding no salt diet, by extracting with $0.05 \mathrm{M}$ pyrophosphate buffer, at $\mathrm{pH} 6.5$. An addition of $10 \mathrm{mM} \mathrm{N}$-cthylmaleimide (NEM) to the buffer did not change the molecular weight of renin extracted.

From human cadaver kidney, low molecular weight renin (M.W. 45,000) was extracted by the same procedure.

In hog kidney, on the other hand, high molecular weight renin (M.W. 67,000 ) was extracted with $0.05 \mathrm{M}$ pyrophosphate buffer, at $\mathrm{pH} 6.5$. High molecular weight renin (M.W. 67,000) was extracted also with the buffer containing $10 \mathrm{mM}$ tetrathionate (TT), a sulf hydryl blocker. However, with the same buffer containing another sulfhydryl blocker, NEM, low molecular weight renin (M.W. 45,000) was extracted. With the buffer containing a sulf hydryl compound, $100 \mathrm{mM}$ dithiothreitol (DTT), low molecular weight renin (M.W. 45,000) was extracted. When NEM was added to the high molecular renin extracted with $0.05 \mathrm{M}$ pyrophosphate buffer, approximately a half of the renin was converted to low molecular weight renin. After acidification to $\mathrm{pH} 3.3$ for $10 \mathrm{~min}$, the high molecular weight renin was converted to low molecular weight renin.

The results were against the assumption that a sulfhydryl requiring enzyme (SH-enzyme) participated in the interconversion between high molecular weight renin and low molecular weight renin.

It is reasonable to assume that the actions of NEM, TT, and DTT are not through a SH-enzyme, but affect directly the interconversion of sulf hydryl group and disulfide (S-S) bond which exists in the renin molecule, and high molecular weight renin may be formed by a combination of low molecular weight renin and another protein with a S-S bond(s).

From the Third Division, Department of Internal Medicine, Faculty of Medicine, Kyoto University, College of Medical Technology,* Kyoto University, and Department of Animal Science, Collage of Agriculture, ${ }^{* *}$ Kyoto University, Kyoto.

Address for reprint: Kenichi Morimoto, M.D., Third Division, Department of Internal Medicine, Faculty of Medicine, Kyoto University, Shogoin, Sakyo-ku, Kyoto City 606, Japan.

Received for publication September 7, 1979. 
Additional Indexing Words :

Gel-filtration Sulfhydryl blocker

bond

Sulfhydryl compound Disulfide

CKEGGS et al ${ }^{11}$ reported 4 different kinds of renin in hog kidney separable $\mathrm{O}$ by ion exchange chromatography. Recently, the presence of renin with different molecular weights has been reported by several investigators. ${ }^{21,31}$ In 1974, Boyd ${ }^{4}$ reported interconvertible hog renins $\mathrm{A}$ and $\mathrm{B}$, with molecular weight 40,000 and 60,000 respectively. In 1975 , Inagami et al ${ }^{51}$ obtained only big renin from hog kidney in the presence of a sulfhydryl blocker, and considered the big renin as the precursor of small active renin. We intended to confirm this finding, but the results did not support their view.

\section{Materials AND Methods}

\section{Materials :}

Hog kidneys were obtained immediately after slaughter. Rat kidneys were obtained from intact and adrenalectomized WKYs immediately after decapitation. The latter were fed with no salt diet for 5 days following the adrenalectomy, and then with usual diet for the next 2 days, and subcutaneously injected $2 \mathrm{mg}$ of furosemide on the 6 th day and $6 \mathrm{mg}$ of desoxycorticosterone acetate (DOCA) on the 7 th day according to the method of De Senarclens et al. ${ }^{6)}$ Human kidneys were obtained from a cadaver 4 hours after death. All the materials were frozen and stored at $-20^{\circ} \mathrm{C}$ until use.

\section{Extraction of renin:}

Kidney cortex (whole kidney in case of rat) were processed as follows. Kidney cortex was homogenized in an ice-water bath with a) $0.05 \mathrm{M}$ pyrophosphate buffer, at $\mathrm{pH} 6.5(5 \mathrm{ml} / 1 \mathrm{Gm}$ of tissue), b) the same buffer containing $10 \mathrm{mMTT}, \mathrm{c})$ the same buffer containing $10 \mathrm{mM}$ NEM, or d) the same buffer containing $100 \mathrm{mM}$ DTT, and centrifuged at $109,000 \times \mathrm{G}$ for 1 hour. The clear supernatant obtained was used for gel-filtration.

\section{Gel-filtration:}

One $\mathrm{ml}$ of a sample was applied to a sephadex $\mathrm{G}-75$ packed column, $1.8 \mathrm{~cm} \times$ $100 \mathrm{~cm}$. The column was eluted at a flow rate of $5 \mathrm{ml} /$ hour with $0.05 \mathrm{M}$ pyrophosphate buffer, $\mathrm{pH} 6.5$, obtaining every $4 \mathrm{ml}$ of effluents. The column was calibrated using bovine serum albumin and chick ovalbumin as molecular standards. All the procedures were performed under $4^{\circ} \mathrm{C}$.

\section{Renin substrate:}

Hog plasma containing disodium-ethylenediaminetetraacetate (EDTA-Na ${ }_{2}$ ) $(1 \mathrm{mg} / \mathrm{ml}$ ) was used as the substrate in the determination of hog renin. It was obtained immediately after slaughter.

Rat blood was obtained 24 hours after bilateral nephrectomy. To the blood was added EDTA-Na $(1 \mathrm{mg} / \mathrm{ml})$ and the plasma was separated for the substrate in the determination of rat renin.

Modifying Skinner's method," a ewe was heparinized with 5,000 I.U. heparin 
48 hours after bilateral nephrectomy, and slaughtered by exsanguination through a canule in the carotid artery. The blood was collected into a pack containing ACD-A solution and EDTA- $\mathrm{Na}_{2}(1 \mathrm{mg} / \mathrm{ml})$, and the plasma was used as the substrate in the determination of human renin.

Renin assay:

To $0.5 \mathrm{ml}$ of a sample was added $1 \mathrm{ml}$ of the corresponding substrate, $1 \mathrm{ml}$ of

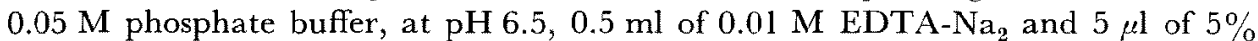
di-isopropylfluorophosphate (DFP). The mixture was incubated for $30 \mathrm{~min}$ at $25^{\circ} \mathrm{C}$. Following the incubation, the tubes were placed in boiling water for $5 \mathrm{~min}$ and the precipitates were removed by centrifugation. Angiotensin I was measured by bioassay or radioimmunoassay. The bioassay was carried out in pentolinum treated rats anesthetized with amobarbital, against angiotensin II amide (hypertensin-Ciba) as the standard. For the radioimmunoassay a commercial kit from CEA-IRESORLIN was used. The activity was expressed in nanograms of angiotensin I released by $1 \mathrm{ml}$ of a sample in 1 hour.

\section{Results}

The peak of hog renin extracted with $0.05 \mathrm{M}$ pyrophosphate buffer was found at the molecular weight of 67,000 in gel-filtration (Fig. 1). Using $10 \mathrm{mM}$ TT in the same buffer, the peak of hog renin activity was also the same (Fig. 2). Using $100 \mathrm{mM} \mathrm{DTT}$ in the same buffer, the peak of renin activity corresponded to the molecular weight of 45,000 (Fig. 3). Using 10 $\mathrm{mM}$ NEM, the peak of renin activity was at the molecular weight of 45,000 (Fig. 4). After acidification to $\mathrm{pH} 3.3$ for $10 \mathrm{~min}$ with $0.5 \mathrm{M} \mathrm{HCl}$ followed by neutralization with $0.5 \mathrm{M} \mathrm{NaOH}$, high molecular weight renin in the hog

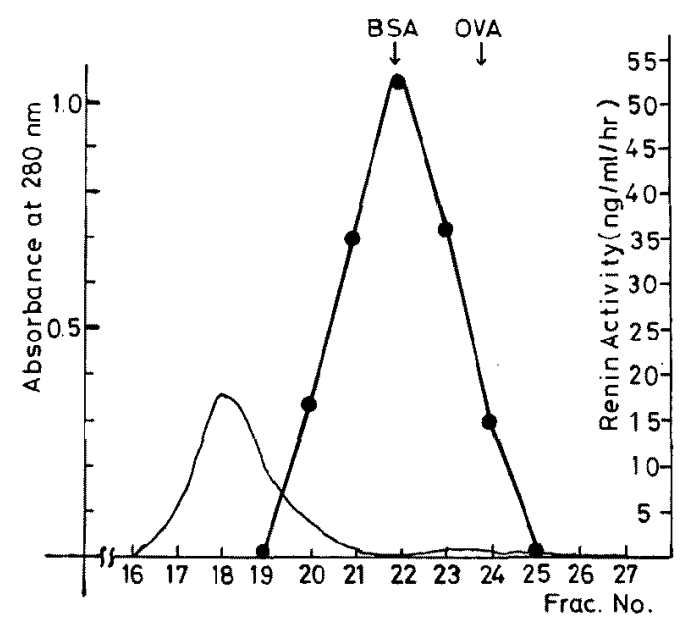

Fig. 1. Hog kidney extract with $0.05 \mathrm{M}$ pyrophosphate buffer, at $\mathrm{pH}$ 6.5. - - = renin activity; - - absorbance at $280 \mathrm{~nm} ; \mathrm{BSA}=$ bovine serum albumin; $O V A=$ ovalbumin. 


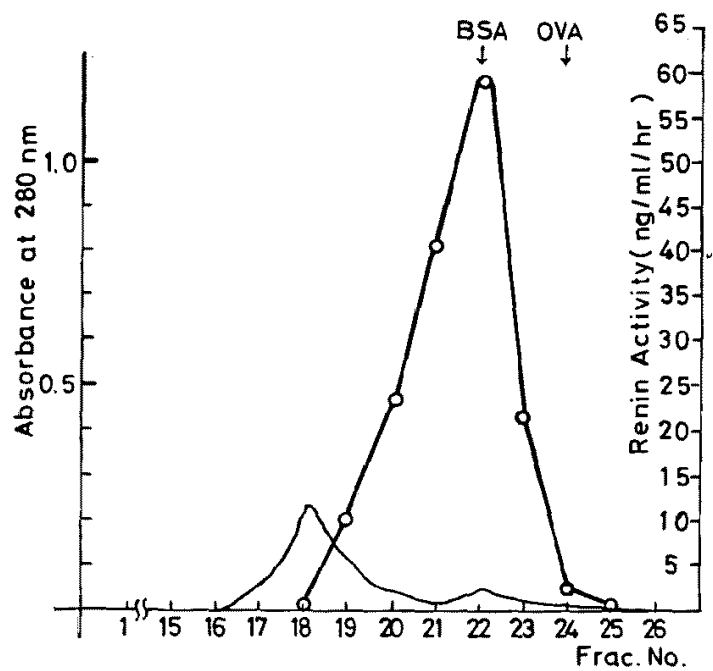

Fig. 2. Hog kidnry extract with $10 \mathrm{mM} \mathrm{TT}$ in $0.05 \mathrm{M}$ pyrophosphate buffer, at $\mathrm{pH} 6.5 . \mathrm{O}-\mathrm{O}=\mathrm{renin}$ activity; - $=$ absorbance at $280 \mathrm{~nm}$; $\mathrm{BSA}=$ bovine serum albumin; OVA = ovalbumin.

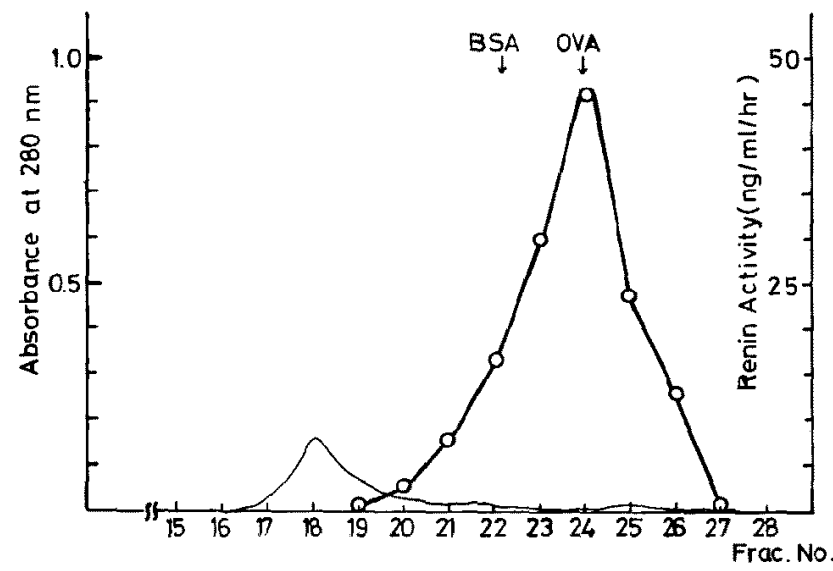

Fig. 3. Hog kidney extract with $100 \mathrm{mM}$ DTT in $0.05 \mathrm{M}$ pyrophosphate buffer, at $\mathrm{pH} 6.5 . \quad \mathrm{O}-\mathrm{O}=$ renin activity; $\longrightarrow=$ absorbance at $280 \mathrm{~nm}$; BSA = bovine serum albumin; OVA =ovalbumin.

kidney extract converted its molecular weight to 45,000 with the total activity nearly unchanged (Fig. 5). However, after dialysis for 24 hours against $0.05 \mathrm{M}$ glycine- $\mathrm{HCl}$ buffer, $\mathrm{pH} 3.3$, the renin activity was lost almost completely (Fig. 5).

Molecular weight of renin of WKY kidney extracted either in the presence or absence of TT was predominantly 45,000 (Fig. 6). In the presence of NEM, the molecular weight of renin was not changed. Renin from the 


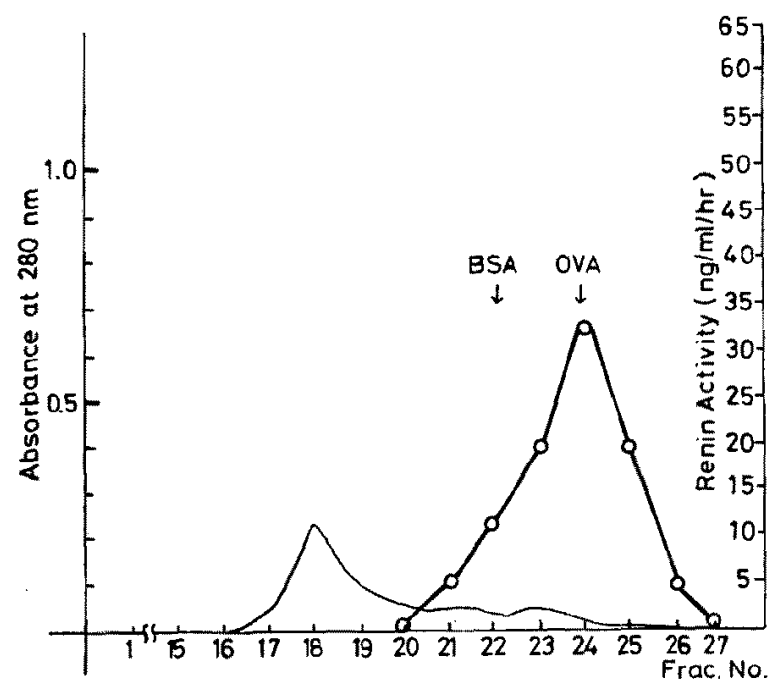

Fig. 4. Hog kidney extract with $10 \mathrm{mM}$ NEM in $0.05 \mathrm{M}$ pyrophosphate buffer, at $\mathrm{pH} 6,5 . \mathrm{O}-\mathrm{O}=$ renin activity; $-=$ absorbance at $280 \mathrm{~nm}$; $\mathrm{BSA}=$ bovine serum albumin; OVA = ovalbumin.

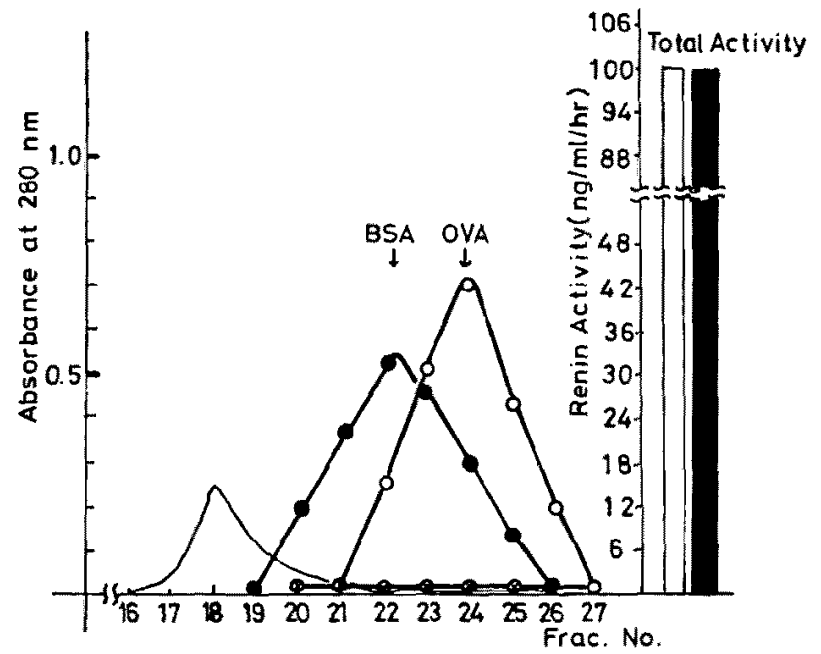

Fig. 5. = renin activity of hog kidney extract with $0.05 \mathrm{M}$ pyrophosphate buffer, at $\mathrm{pH} 6.5 ; \mathrm{O}-\mathrm{O}=$ renin activity after acidification for $10 \mathrm{~min} ; \theta-Q=$ renin activity after dialysis for 24 hours against $0.05 \mathrm{M}$ glycine-HCl buffer, pH 3.3; - =absorbance at $280 \mathrm{~nm} ; \mathrm{BAS}=$ bovine serum albumin; OVA = ovalbumin.

adrenalectomized WKY showed no difference in molecular weight from that of the intact rat irrespective of the presence of NEM (Fig. 7).

Human cadaver kidney renin activity showed a peak at the molecular 


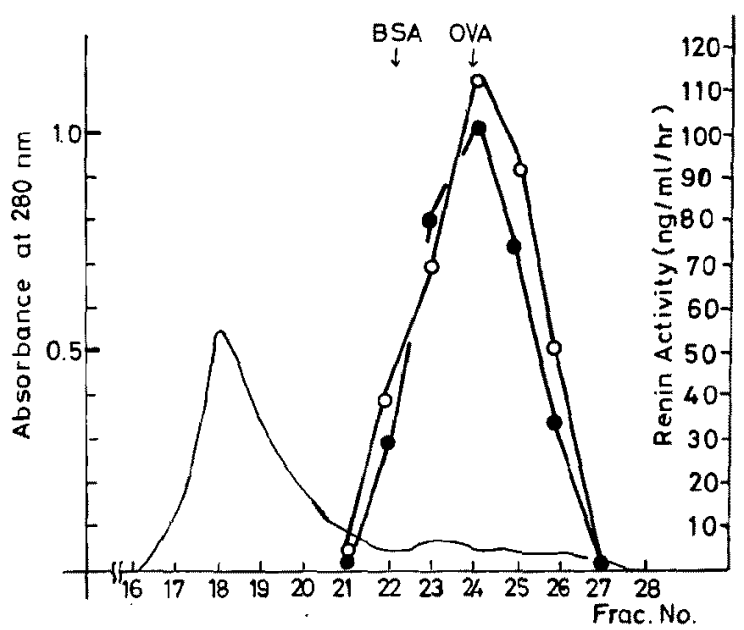

Fig. 6. Renin activity of WKY kidney extract. $O-O=$ with $10 \mathrm{mM}$ TT in $0.05 \mathrm{M}$ pyrophosphate buffer, at pII $6.5 ;-0=$ without TT in the same buffer; - $=$ absorbance at $280 \mathrm{~nm} ; \mathrm{BSA}=$ bovine serum albumin; OVA = ovalbumin

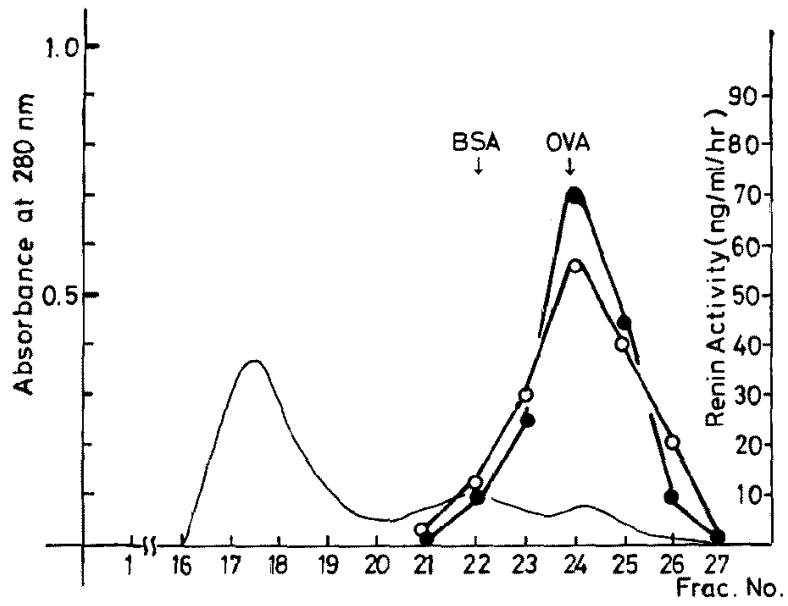

Fig. 7. Renin activity of adrenalectomized WKY kidney extract. $\mathrm{O}-\mathrm{O}=$ with $10 \mathrm{mM} \mathrm{NEM}$ in $0.05 \mathrm{M}$ pyrophosphate buffer, at $\mathrm{pH} 6.5$; - without NEM in the same buffer; - $=$ - =absorbance at $280 \mathrm{~nm}$; $\mathrm{BSA}=$ bovine serum albumin; OVA = ovalbumin .

weight of 45,000 irrespective of the presence of NEM or TT in the buffer (Fig. 8).

\section{Discussion}

Inagami et $\mathrm{al}^{8)}$ stated that high molecular weight renin (M.W. 63,000) in the hog kidney was the native form, and it is able to be extracted only when 


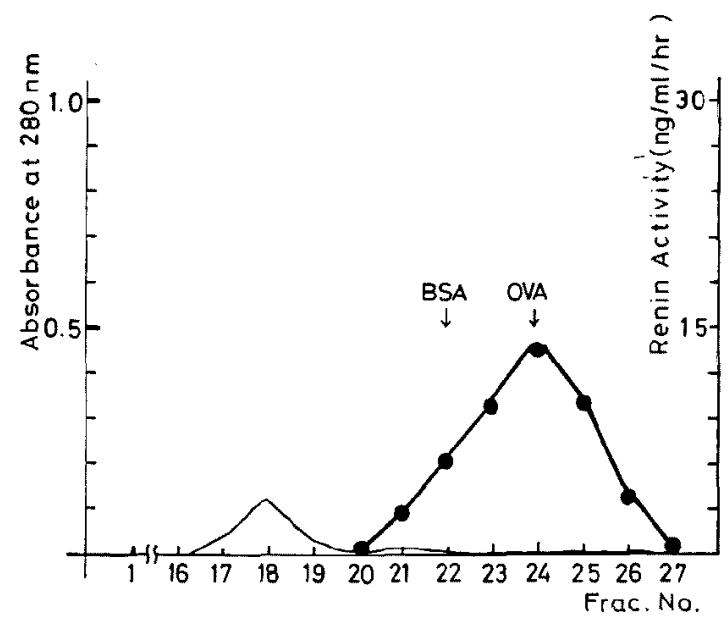

Fig. 8. Human kidney extract with $0.05 \mathrm{M}$ pyrophosphate buffer, at $\mathrm{pH}$ 6.5. - = renin activity; - absorbance at $280 \mathrm{~nm} ; \mathrm{BSA}=$ bovine serum albumin; OVA = ovalbumin.

the buffer contains sulfhydryl blockers such as NEM and TT. In another words, during extraction process sulfhydryl-requiring enzymes (SH-enzymes) catalyze the conversion of high molecular weight renin to low molecular weight renin, while high molecular weight renin is preserved in the presence of sulfhydryl blocker. However, our studies did not support their hypothesis. By extracting hog kidney with a buffer without any sulfhydryl blocker high molecular weight renin (M.W. 67,000) was obtained, whereas by using $10 \mathrm{mM}$ NEM in the same buffer, low molecular weight renin (M.W. 45,000) was extracted. On the other hand, in the presence of $10 \mathrm{mM}$ TT, a sulfhydryl blocker similar to NEM, high molecular weight renin (M.W. 67,000) was obtained. Although both NEM and TT were sulfhydryl blockers, the effects on a renin molecule were different.

If a SH-enzyme participates in the interconversion between high molecular weight renin and low molecular weight renin, the next 2 assumptions are possible.

1) The enzyme may convert high molecular weight renin to low molecular weight renin.

Provided the enzyme existed as an active form, the experimental results obtained with DTT and TT were consistent with this assumption. DTT provided the enzyme sulfhydryl group and accelerated the production of low molecular weight renin. TT inhibited the enzyme by blocking sulfhydryl group and high molecular weight form remained unchanged. However, the experimental results with the buffer containing NEM or with the buffer alone were contradictory to the assumption. Extracting with buffer alone, high 
molecular weight renin was extracted predominantly, in spite of the presence of the active enzyme. Low molecular weight renin was extracted in the presence of NEM which inhibited SH-enzyme by blocking the sulfhydryl group.

Even when the enzyme existed as an inactive form, the result obtained with NEM was also contradictory to the assumption. Other 3 results were consistent with the assumption when the enzyme was inactive. DTT activated the inactive enzyme by providing sulfhydryl group and produced low molecular weight renin. High molecular weight renin was obtained with the buffer alone or in the presence of TT, since the enzyme remained inactive.

2) The enzyme may convert low molecular weight renin to high molecular weight renin.

In this assumption, provided the enzyme existed as an active form, high molecular weight renin should be extracted with the buffer alone or in the presence of DTT, and low molecular weight renin should be extracted in the presence of NEM or TT which inactivated SH-enzymes by blocking sulfhydryl group. Howcver, the results with DTT and TT were contradictory to the assumption.

On the other hand, provided the enzyme existed as an inactive form, low molecular weight renin should be extracted with the buffer alone or in the presence of NEM or TT, and high molecular weight renin should be extracted in the presence of DTT which activated SH-enzyme. The results were contradictory to the assumption except in the experiment with NEM.

Hence it is contradictory to assume that a SH-enzyme participates in the interconversion between high molecular weight renin and low molecular weight renin. Alternatively, it is possible to explain all the experimental results by assuming that NEM, TT, and DTT may directly act on a renin molecule. If the low molecular weight renin is bound with another protein by S-S bond to form the high molecular weight renin, DTT may split a high molecular weight renin to a low molecular weight renin and a binding protein by reducing the $\mathrm{S}-\mathrm{S}$ bond. A sulfhydryl blocker, TT, does not affect $\mathrm{S}-\mathrm{S}$ bond of high molecular weight renin and there was no conversion of high molecular weight renin. As for the effect of NEM, it is possible that NEM may convert high molecular weight renin to low molecular weight renin by splitting off the S-S bond, since about half of the high molecular weight renin was converted to low molecular weight renin by the addition of NEM to the extract with pyrophosphate buffer alone. Funakawa et $\mathrm{al}^{{ }^{9}}$ indicated that dog renin was stored in the granules as a low molecular weight form and high molecular weight renin was a renin-protein complex produced by binding with a substance in the renal cortex tissue. They also showed an involvement of sulfhydryl group in the interconversion of 2 forms. This is compatible with our 
assumption.

Levine et $\mathbf{a l}^{\mathbf{1 0})}$ obtained high molecular weight renin (M.W. 60,000) from hog kidney extract either in immediate contact with toluene which insolubilized $75 \%$ of the protein or in contact to toluene 2 hours after extraction. Acidification converted the high molecular weight renin to low molecular weight renin with a loss of $20-30 \%$ of total activity and a concomitant " purification". They concluded that high molecular weight renin was not a precursor although significance of the high molecular weight renin was not clear. Their result that high molecular weight renin was obtained without sulfhydryl blocker is consistent with ours.

Low molecular weight renin was found predominantly in human kidney irrespective of the presence of sulfhydryl blockers.

To evaluate the hypothesis that high molecular weight renin was the precursor of low molecular weight renin, the molecular weight of renin was investigated in kidneys of WKY whose renin-angiotensin system was stimulated by bilateral adrenalectomy. According to De Senarclens et al ${ }^{6)}$ newly synthesized renin in this condition was acid activatable form but no comment on its molecular weight. Our experimental results showed no evidence that the newly synthesized renin in adrenalectomized rat had a high molecular weight irrespective of the presence of sulfhydryl blockers.

\section{REFERENCES}

1. Skeggs LT, Lentz KE, Kahn JR, Hochstrasser H: Studies on the preparation and properties of renin. Circulat $\operatorname{Res}$ 20-21 (Suppl II): 91, 1967

2. Day RP, Luetscher JA, Gonzales CM: Occurrence of big renin in human plasma, amniotic fluid and kidney extracts. JCE \& M 40: 1078, 1975

3. Rubin I: Purification of hog renin. Properties of purified hog renin. Scand J Clin Lab Invest 29: 51, 1972

4. Boyd GW: A protein-bound form of porcine renal renin. Circulat Res 35: 426, 1974

5. Inagami $T$, Murakami $K$ : Purification of renin precursor from hog kidney. Circulation 51 (Suppl II): 14, 1975 (abstr)

6. De Senarclens CF, Pricam CE, Banichahi FD, Vallolton MB: Renin synthesis, storage and release in the rat. A morphological and biochemical study. Kidney Int 11:161, 1977

7. Skinner SL: Improved assay methods for renin " concentration " and "activity " in human plasma. Circulat Res 20: 391, 1967

8. Inagami T, Hirose S, Murakami K, Matoba $\mathrm{T}$ : Native form of renin in the kidney. J Biol Chem 252: 7733, 1977

9. Funakawa S, Funae Y, Yamamoto K: Conversion between renin and high-molecular-weight renin in the dog. Biochem J 176: 977, 1978

10. Levine M, Lentz KE, Kahn JR, Dorer FE, Skeggs LT: Studies on high molecular weight renin from hog kidney. Circulat Res 42: 368, 1978 